Original Research Paper

\title{
Pembinaan dan Pendampingan Teknik Budidaya Trigona sp Bagi Peternak Kecil di Kabupaten Lombok Barat
}

\author{
Baiq Yulfia Elsadewi Yanuartati ${ }^{1 *}, \operatorname{Ridwan}^{1}$, Johan Bachry ${ }^{1}$, Hayati $^{1}$, M. Zubair ${ }^{1}$ \\ ${ }^{1}$ Jurusan Sosial Ekonomi Fakultas Pertanian, Universitas Mataram, Mataram, Indonesia.
}

https://doi.org/10.29303/jpmpi.v3i2.1131

Sitasi: Yanuartati, B. Y. E., Ridwan., Bachry, J., Hayati \& Zubair, M. (2021). Pembinaan dan Pendampingan Teknik Budidaya Trigona sp Bagi Peternak Kecil di Kabupaten Lombok Barat. Jurnal Pengabdian Magister Pendidikan IPA, 4(4)

\section{Article history}

Received: 15 September 2021

Revised: 20 September 2021

Accepted: 30 November 2021

*Corresponding Author Bq.

Rani Dewi Wulandani,

Jurusan Sosial Ekonomi

Fakultas Pertanian, Universitas

Mataram, Mataram, Indonesia.

Email: yulfiae@unram.ac.id

\begin{abstract}
Kabupaten Lombok Barat, terutama Kecamatan Gunung Sari memiliki sumberdaya alam dan iklim yang sangat cocok untuk perkembangan lebeh Trigona sp. Lebah ini memiliki nilai ekonomis tinggi dan relatif sangat mudah untuk dibudidayakan. Apalagi lebah ini tidak menyengat sehingga bisa dibudidayakan bahkan oleh anak-anak. Saat ini permintaan madu Trigona sp di pasar lokal NTB dan nasional semakin hari semakin meningkat. Apalagi sejak Covid19, polen dan madu Trigona diindikasikan oleh beberapa penelitian internasional dapat membantu penyembuhan pasien terdampak Covid19. Saat ini, sudah mulai ada peternak yang membudidayakan lebah Trigona sp di Kecamatan Gunungsari, termasuk di desa Taman Sari. Akan tetapi, para peternak masih menggunakan cara tradisional dan belum mendapatkan pengetahuan dan keterampilan budidaya yang tepat guna. Akibatnya produksi Trigona mereka masih sangat rendah. Oleh karena itu, PKM ini memperkenalkan teknologi inovasi budidaya lebah Trigona yang dapat membantu mereka meningkatkan produksi. Teknologi inovasi ini juga dijamin mudah untuk diadopsi oleh para peternak karena teknologinya sederhana.
\end{abstract}

Keywords: Pemberdayaan, Trigona sp, panen, pascapanen, pemasaran

daerah Gunung Sari Kabupaten Lombok Barat ini sebagian belum tersentuh pendampingan budidaya sesuai dengan inovaasi yang telah dikembangkan. Masih banyak peternak menggunakan cara tradisional dan belum mendapatkan pengetahuan dan keterampilan budidaya yang tepat guna. Akibatnya produksi Trigona sp mereka masih sangat rendah. Oleh karena itu, kegiatan PKM ini memperkenalkan teknologi inovasi budidaya lebah Trigona yang dapat membantu mereka meningkatkan produksi. Teknologi inovasi ini juga dijamin mudah untuk diadopsi oleh para peternak karena teknologinya sederhana.

Kegiatan pengabdian ini memberikan pengetahuan dan keterampilan melalui kegiatan pelatihan dan pendampingan sampai para peternak terbiasa dengan teknik budidaya Trigona hasil inovasi dari ahli di bidang ini. Inovasi budidaya Trigona ini relative mudah untuk dilakukan dan 
dapat meningkatkan produksi lebah para peternak. Diharapkan kegiatan ini dapat memotivasi peternak yang ada dan penduduk sekitarnya untuk melakukan pengembangan Trigona dan menigkatkan penghasilan keluarga. Pendampingan dilakukan secara intensif untuk memberikan kesempatan konsultasi individual petani dengan tim Pembina. Tim ini juga melakukan pembenahan yang berkelanjutan untuk memperbaiki proses pemmberdayaan/pembinaan.

Tujuan dari kegiatan pengabdian masyarakat ini adalah untuk melatih dan mendampingi peternak kecil Trigona sp untuk melakukan budidaya ternak lebah Trigona sp sesuai dengan teknologi inovasi sehingga diharapkan mampu meningkatkan produksi Trigona sp. Menambah tanaman pakan bagi Trigona sp untuk meningkatkan produksi ternak ini. Melakukan pembinaan kelompok dan individu untuk bersama-sama peternak

\section{Metode}

Metode yang digunakan dalam kegiatan pengabdian kepada masyarakat ini adalah metode partisipatif dan interaktif dengan pendampingan yang intensif. Hal ini semakin dipermudah karena tim bekerjasama dengan petugas lapangan di lokasi pembinaan. Petugas lapangan yang dilibatkan merupakan seorang ahli peternakan Trigona sp dan alumni dari Universitas Mataram (Sukri, SPt.) yang sudah memiliki pengalaman 10 tahun di Kabupaten Lombok Utara mendampingi para peternak Trigona sp dalam hal budidaya. Ada dua orang petugas lapangan lainnya yang merupakan ahli budidaya Trigona sp juga dilibatkan dalam kegiatan ini untuk memonitor perkembangan lebah di rumah-rumah peternak yang sudah mendapatkan pelatihan. Dalam pelaksanaan kegiatan, tim penyuluhan dan pendamping lapangan berkunjung ke lokasi peternakan para peternak kecil. Pertemuan dan pelatihan kelompok dilakukan beberapa kali. Selanjutnya pendampingan dan konsultasi akan bersifat individu karena waktu panen dan kebutuhan panen para peternak berbeda-beda.

Lokasi kegiatan pembinaan kepada masyarakat ini dilakukan di Desa Taman Sari Kecamatan Gunungsari. Kedua lokasi ini merupakan lokasi peternak Trigona sp yang belum mendapatkan pembinaan sebelumnya.

\section{Hasil dan Pembahasan}

Sesuai dengan tujuan kegiatan, ada beberapa poin penting untuk didiskusikan di antaranya adalah pentingnya aspek budidaya Trigon asp bagi peternak kecil. Selain itu, paper ini menyorot tentang pelaksanaan pembinaan, pendampingan, dan evaluasi kegiatan dalam upaya pemberdayaan masyarakat yang rentan di daerah terpencil.

\section{a. Aspek Budidaya Trigona sp}

Budidaya Trigona sp relatif mudah dilakukan karena alat bahan yang digunakan sederhana, serta proses pemeliharaan yang tidak memerlukan tenaga kerja yang banyak maupub proses yang rumt. Akan tetapi, dikarenakan budidaya Trigona sp ini merupakan komoditi yang relative baru dikenal masyarakat, masih banak peternak yang belum memahami cara budidaya yang benar. Sementara itu, telah ada beberapa hasil penelitian, terutama dari Universitas Mataram yang merekomendasikan teknik budidaya yang dapat memberikan hasil yang optimal untuk panen lebah tak bersengat ini (Setiawan, dkk, 2021).

\section{b. Persiapan Kegiatan Pembinaan Peternak Trigona sp}

Sejak kegiatan ini dinyatakan dimulai, tahapan persiapan dari awal kegiatan pemberdayaan sampai akhir sudah telah dlakukan.Persiapan ini meliputi persiapan konsep yang meliputi teknik pelatihan, pendampingan, monitoring dan evaluasi kegiatan, sampai pelaporan. Alokasi dan estimasi biaya riil di lapangan juga dilakukan dengan bantuan mahasiswa yang diajak terlibat dalam kegiatan ini dan juga teknisi lapangan.

Komunikasi juga sudah dimulai bersama dengan teknisi di lapangan dan mahasiswa yang direkrut untuk kegiatan ini. Diskusi dengan mereka untuk menentukan jadwal kesiapan untuk mengeksekusi di lapangan. Setelah kesepakatan dicapai, rangkaian kegiatan mulai dibicarakan dalam rapat persiapan. Tim lapangan mendapatkan penjelasan tujuan dari kegiatan ini dan langkahlangkah yang akan dilakukan. Tim juga memberikan masukan sesuai dengan kondisi lapangan yang mereka pahami.

Setelah pertemuan dengan tim lapangan, kemudian perwakilan tim mengontak petani melalui 
teknisi lapangan. Tim Unram mendatangi lokasi para peternak untuk melakukan sosialisasi kegiatan. Dalam kegiatan ini, perwakilah tim memperkenalkan diri dan tim Unram yang terlibat dalam kegiatan ini.

Kunjungan ke lokasi bertujuan untuk melihat kondisi budidaya dan melakukan survey untuk memperkirakan keperluan peternak terhadap pelatihan dan pendampingan ini. Kunjungan ini didampingi oleh teknisi lapangan yang sudah mulai melakukan pendampingan dalam beberapa bulan terakhir. Lokasi yang dipilih adalah lokasi di mana para peternak belum pernah mendapatkan pelatihan budidaya sebelumnya.

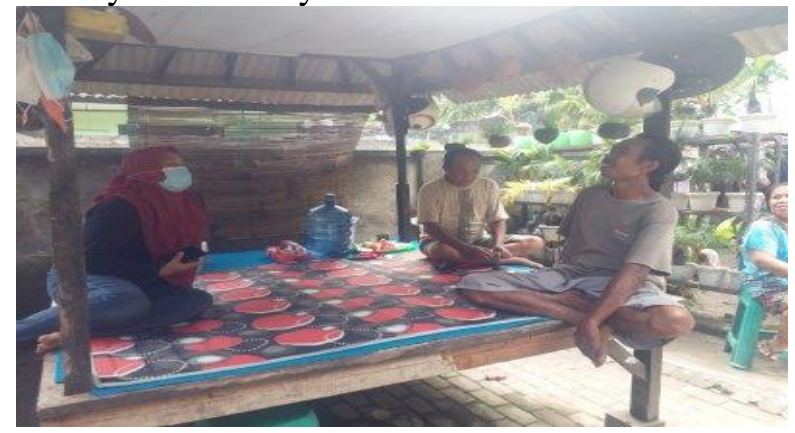

Gambar 1. Sosialisasi Kegiatan Kepada Peternak Lebah Trigona sp

Kunjungan awal juga dilakukan untuk melakukan sosialisasi terkait proyek pemberdayaan yang akan dilakukan oleh Tim Unram kepada beberapa pengurus kelompok. Mereka menyambut baik kegiatan ini karena mereka selama ini masih melakukan budidaya secara otodidak. Mereka tidak memiliki standar kotak dan jenis-jenis pakan yang dapat meningkatkan produksi lebah.

Kegiatan selanjutnya adalah kegiatan turun lapangan melakukan persiapan pelatihan. Selanjutnya dilakukan rapat koordinasi dengan fasilitator, dan mahasiswa yang dilibatkan terkait dengan pelaksanaan pelatihan. Koordinasi ini utuk menyepakati waktu, tempat, dan cara pelaksaan pelatihan. Selanjutnya dilakukan koordinasi dengan ketua kelompok di Desa Taman Sari Kecamatan Gunung Sari, kemudian dilakukan penyebaran undangan. Persiapan alat pembuatan kotak, pembelian bibit lebah dan bibit tanaman pakan melibatkan mahasiswa dan fasilitator.

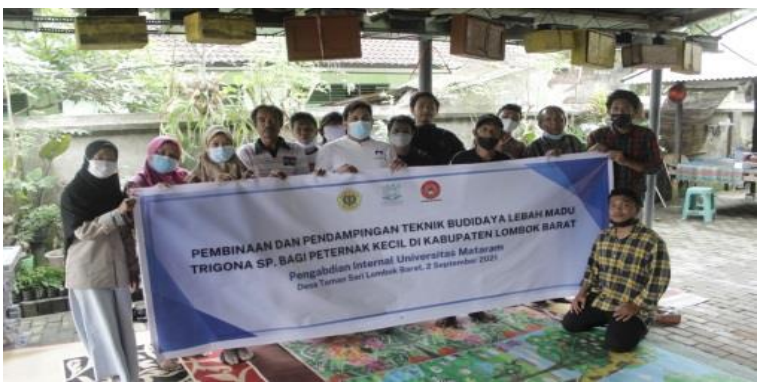

Gambar 2. Para Peserta dan tim Pelatihan Budidaya Lebah Trigona sp

Pada acara pelatihan yang diikuti oleh 10 orang peternak dan beberapa mahasiswa yang ingin belajar cara beternak Trigona secara voluntir bergabung dalam pelatihan ini. Pelatihan dimulai dengan seremonial pembukaan dari tim dan dilakukan responsi awal untuk mengetahui tingkat pemahaman mereka terhadap teknik budidaya dan juga mengetahui harapan mereka dalam ha keterampilan yang ingin mereka tingkatkan dari pelatihan ini. Dari response awal ini, tim pelatih mengetahui mana aspek yang perlu difokuskan untuk peternak. Materi yang diberikan sebanyak 2 (dua) sesi, yaitu terkait dengan dinamika kelompok, dan teknik budidayan. Untuk dinamika kelompok, peternak dijelaskan mengenai pentingnya bekerja dalam kelompok untuk meningkatkan akses kepada sumberdaya yang mendukung usaha ternak mereka, dan juga proses-proses lainnya. Untuk sesi kedua, para peternak diberikan materi tentang jenis pakan, ukuran kotak, dan cara pemindahan koloni yang sesuai dengan hasil penelitian. Kebanyakan peternak tidak memebrikan perhatian pada aspek ini sehingga perkembangan koloni mereka cenderung lamban dan menghasilkan madu yang sedikit. Penelitian ini memberikan tambahan pengetahuan baru tentang teknik meningkatkan produksi Trigona sp. Pelatihan ditutup dengan kegiatan penyerahan tanaman pakan dan responsi akhir untuk mengevaluasi hasil dari pelatihan.

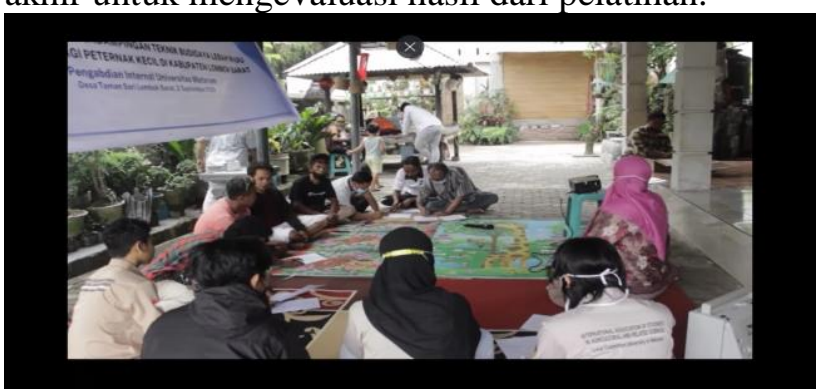

Gambar 3. Pelaksanaan Pelatihan Budidaya Lebah Trigona sp 
Pelaksanaan Pembinaan, Pendampingan, dan Evaluasi Kegiatan dalam Pemberdayaan Peternak Trigona sp

Hasil dari evaluasi kegiatan bersama dengan para peternak dan pengurus kelompok peternak Trigona sp di Desa Taman Sari ini, diperoleh beberapa kesepakatan di antara mereka bahwa mereka merasakan manfaat dari pembinaan yang dilakukan dalam kegiatan ini. Sebagian dari peternak belum mendapatkan pembinaan sebelumnya. Evaluasi kegiatan ini merupakan bagian dari implementasi dari pemberdayaan masyarakat yang partisipatif, dimana proses pengembangan masyarakat lebih efektif ketika melibatkan sasaran program untuk ikut serta dari keseluruhan proses implementasi dan dapat menyampaikan aspirasi dan permasalahan mereka (Joseph, 2020).

Selain pendekatan kelompok, penelitian individual juga dirasakan perlu dilakukan seperti yang dilakukan dalam kegiatan pemberdayaan di Kecamatan Gunung Sari ini. Hal ini untuk mengakomodir kondisi peternak yang berbedabeda. Sesuai dengan Mersha \& Van Laerhoven, (2016) bahwakondisi dari individu yang berbedabeda menyebabkan masyarakat sasaran kegiatan pemberdayaan juga memberikan respon berbedabeda terhadap program yang diberikan. Akan tetapi, dalam kegiatan di Desa Taman Sari ini, keterbatasan waktu dan biaya menjadi permasalahan utama karena program ini tergantung pada pembiayaan dari eksternas semisal proyek pemberdayaan yang dilakukan oleh Universitas Mataram ini.

Selanjutnya, kegiatan evaluasi dan monitoring perlu dilakukan terhadap kegiatan budidaya peternak yang menjadi sasaran kegiatan pemberdayaan seperti ini. Monitoring yang teratur kepada peternak yang dibina dapat membantu mereka untuk mengidentifikasi permasalahan yang dihadapi dan dapat mengetahui bentuk pendampingan lanjutan yang mereka perlukan. Hal ini sesuai dengan Kariuki (2014) tentang pentingnya proses evaluasi dilakukan dalam pelaksanaan program pengembangan masyarakat.

\section{Kesimpulan}

\begin{tabular}{lllr}
\multicolumn{2}{c}{ Berdasarkan } & proses & pemberdayaan \\
masyarakat terpencil & dengan & menggunakan \\
sumberdaya lokal, dan refleksi yang telah
\end{tabular} dilakukan, ada beberapa hal yang dapat disimpulkan. Pertama, Kegiatan budidaya ternak Trigona sp ini telah memberikan pengetahuan dan keterampilan baru kepada peternak kecil dalam memanfaatkan inovasi untuk meningkatkan produktivitas lebah mereka melalui adopsi inovasi tknik budidaya sesuai dengan hasil studi akademis. Kedua, kegiatan pendampingan dan pelatihan perlu terus dilanjutkan untuk memberikan perkembangan inovasi untuk meningkatkan produksi peternak. Ketiga, dikarenakan pakan merupakan salah satu komponen terpenting dalam budidaya Trigona sp, peternak juga perlu diberikan pengenalan yang berkelanjutan tentang pengelolaan tanaman pakan.

\section{Daftar Pustaka}

Joseph, R. (2020). The theory of empowerment: A critical analysis with the theory evaluation scale. Journal of Human Behavior in the Social Environment, 30(2), 138-157.

Kariuki, J. G. (2014). An exploration of the guiding principles, importance and challenges of monitoring and evaluation of community development projects and programmes. International Journal of Business and Social Science,, 5(1), 140-147

Mersha, A., \& Van Laerhoven, F. (2016). A gender approach to understanding the differentiated impact of barriers to adaptation: responses to climate change in rural Ethiopia. Regional Environmental Change, 16(6), 1701-1713. doi:10.1007/s10113-015-0921-z

Sahlan, M., Irdiani, R., Flamandita, D., Aditama, R., Alfarraj, S., Ansari, M. J., . . . Lischer, K. (2021). Molecular interaction analysis of Sulawesi propolis compounds with SARSCoV-2 main protease as preliminary study for COVID-19 drug discovery. Journal of King Saud University-Science, 33(1), 101234.

Setiawan A., Susdiyanti T., dan Meiganati K.B. 2021). Produktifitas Lebah Trigona sp. pada Berbagai Teknik Budidaya di Desa Nayagati Kecamatan Leuwidamar Kabupaten Lebak. Jurnal Nusa Sylva, 21 (1). 2797-4502. 